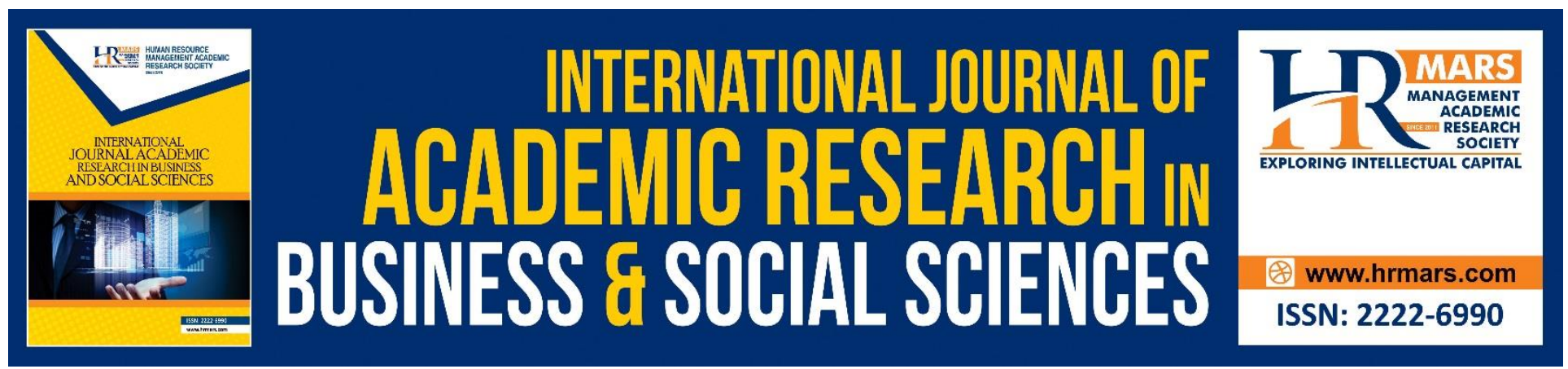

\title{
The Effect of Tax Knowledge, Self Assessment System, and Tax Awareness on Taxpayer Compliance
}

Asrinanda, Yossi Diantimala

To Link this Article: http://dx.doi.org/10.6007/IJARBSS/v8-i10/4762

DOI: $10.6007 /$ IJARBSS/v8-i10/4762

Received: 13 Sept 2018, Revised: 19 Oct 2018, Accepted: 16 Oct 2018

Published Online: 30 October 2018

In-Text Citation: (Asrinanda, 2018)

To Cite this Article: Asrinanda, Y. D. (2018). The Effect of Tax Knowledge, Self Assessment System, and Tax Awareness on Taxpayer Compliance. International Journal of Academic Research in Business and Social Sciences, 8(10), 539-550.

Copyright: (C) 2018 The Author(s)

Published by Human Resource Management Academic Research Society (www.hrmars.com)

This article is published under the Creative Commons Attribution (CC BY 4.0) license. Anyone may reproduce, distribute, translate and create derivative works of this article (for both commercial and non-commercial purposes), subject to full attribution to the original publication and authors. The full terms of this license may be seen

at: http://creativecommons.org/licences/by/4.0/legalcode

Vol. 8, No. 10, 2018, Pg. 539 - 550

http://hrmars.com/index.php/pages/detail/IJARBSS

JOURNAL HOMEPAGE

Full Terms \& Conditions of access and use can be found at http://hrmars.com/index.php/pages/detail/publication-ethics 


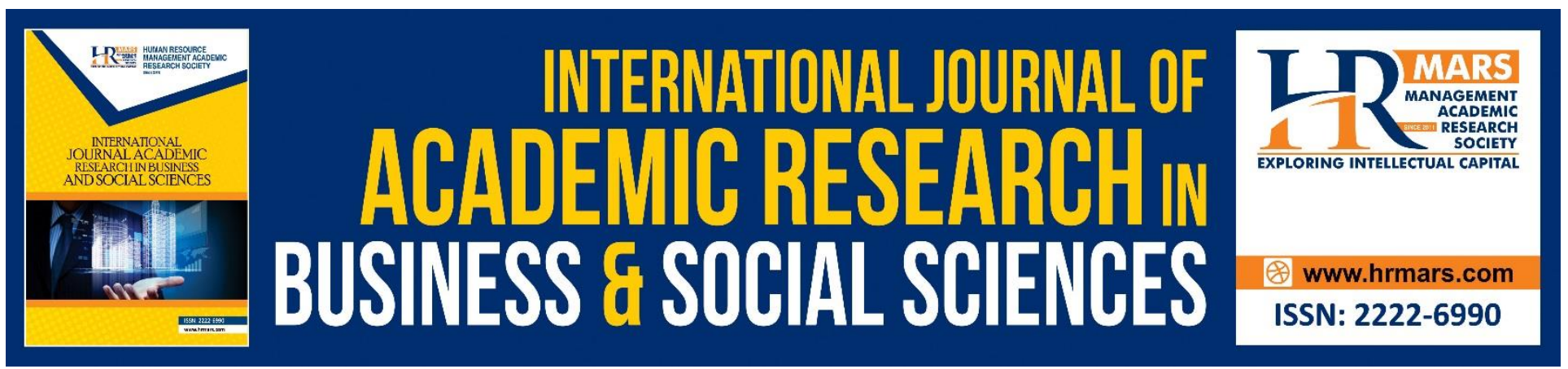

\title{
The Effect of Tax Knowledge, Self Assessment System, and Tax Awareness on Taxpayer Compliance
}

\author{
Asrinanda, Yossi Diantimala \\ Magister Akuntansi Program Pascasarjana Universitas Syiah Kuala Banda Aceh \\ Fakultas Ekonomi Universitas Syiah Kuala
}

\begin{abstract}
This research was conducted to examine the influence of tax knowledge, self assessment system and tax awareness on taxpayer compliance in Banda Aceh City. The sampling technique used is simple randaom sampling that is a simple random sampling, so that the obtained sample of 100 respondents. Knowledge taxation, self assessment system and tax awareness both simultaneously and partially significant effect on taxpayer compliance in Banda Aceh City. Variation of taxation knowledge, self assessment system and tax awareness affect the taxpayer compliance variation of 93.1 percent and the rest of 6.9 percent influenced by other variables outside this research model. In improving taxpayer compliance within Banda Aceh City government is required to socialize the importance of taxes for development so that it will create awareness of taxation and public knowledge in paying taxes.
\end{abstract}

Keywords: Tax Knowledge, Self Assessment System, Taxpayer Awareness and Taxpayer Compliance

\section{Introductions}

Taxes can be interpreted as a source of funds from a country to overcome various problems such as social problems, welfare improvement, prosperity and become a social contract between the government and its citizens (Ruyadi, 2012). There are many factors affecting the tax revenue of a country such as the level of taxpayer compliance in the country (Chau, 2009). If the society becomes more aware and obedient to taxation, it will affect the increase of domestic tax revenue. Another factor that also affects tax revenues is the understanding of taxpayers on the implementation of self assessment system in carrying out tax obligations of taxpayers measured based on the understanding of Taxpayers on the obligation to calculate, calculate, pay, and report the tax payable (Lestari, 2010). The self-assessment of the self-assessment system carries the mission and consequences of changing the attitude (consciousness) of the citizens to pay taxes voluntarily (Harahap, 2004: 43).

The taxpayer is responsible for self-determination of his tax obligations and then accurately and timely pay and report the tax (Devano and Rahayu, 2006: 110). The weakness of the self- 
assessment system that gives the Taxpayer the confidence to calculate, calculate, pay, and report his own tax payable in practice is difficult to run as expected, even abused (Tarjo and Indrawati, 2006). The implementation of the self assessment system in the tax system is not fully functional, as some Tax Office still get obstacles and obstacles in the implementation of taxation, among others is notification letter (SPT), filled and reported by the Taxpayer is difficult to detect (Hutagaol, $2007: 4$ ). In addition Taxpayers do not want to rely on relying on their own information and reports.

The condition of taxation that requires the active participation of the Taxpayer in conducting taxation requires high taxpayer compliance, that is compliance in fulfillment of tax obligation is done by the Taxpayer (done by themselves or assisted by experts such as tax practitioner) instead of Fiskus as tax collector (Rahayu , 2010: 137).

The main problem currently faced by the Directorate General of Taxes of the Ministry of Finance is the low compliance of the people to taxation, when the tax collection system shifts from the official assessment (the process of calculation is done by the Directorate General of Taxes) to self assessment (the process of self-calculation by taxpayers) as it is today, then there are some requirements that must be met first, the requirement is the level of knowledge of good enough tax in the community and the high level of honesty in filling and reporting tax letters (SPT), but unfortunately these two requirements have not been met and the implementation of the system self assessment is not optimal, so the impact of tax compliance level is still low (Chandra, 2014).

The issue of taxpayer compliance is an important issue throughout the world, for both developed and developing countries, because if the taxpayer does not comply then it will create a desire to take avoidance, evasion, smuggling and tax evasion, which ultimately leads to the acceptance the state tax will decrease (Rahayu, 2010: 140).

The level of compliance of the Indonesian people to pay taxes is still low, only about $30 \%$ of Indonesians are willing to pay taxes, $70 \%$ of private persons who are able in Indonesia do not pay taxes, if calculated 70\%, the value can reach Rp 300-400 trillion, still low Indonesians to pay taxes due to awareness issues, people who do not pay taxes do not give the state rights so it is similar to corruption (Fuad, 2014).

The low level of taxpayer compliance and the submission of the Annual Income Tax Returns, due to the lack of knowledge of the taxpayer community about his obligations in paying taxes (Yoepidha, 2012). The statement is in line with that stated by Fuad (2014) which says it is fair if many people are not yet obedient to pay taxes, this is because the public knowledge about taxes is still low, as well as those presented by the head of extension, service and public relations Regional Office Directorate General of Tax Taxpayer. Haroen, (2013) argues that the knowledge of taxes obtained by the public is not yet optimal, of about 250 million Indonesians, there are 22 million registered taxpayers but not all of them pay tax accordingly. 
INTERNATIONAL JOURNAL OF ACADEMIC RESEARCH IN BUSINESS AND SOCIAL SCIENCES Vol. 8, No. 10, Oct. 2018, E-ISSN: 2222-6990 @ 2018 HRMARS

Table 1

Number of Registered Taxpayers and Reporting Tax Return on Prataman Tax Office (KPP) Kota Banda Aceh

\begin{tabular}{|c|c|c|c|c|}
\hline Year & $\begin{array}{c}\text { Number of WP } \\
\text { Registered }\end{array}$ & $\begin{array}{c}\text { Developments } \\
\text { (\%) }\end{array}$ & $\begin{array}{c}\text { Number of } \\
\text { WP Reports }\end{array}$ & $\begin{array}{c}\text { Development } \\
\text { (\%) }\end{array}$ \\
\hline 2011 & 129.379 & - & 62.516 & - \\
\hline 2012 & 140.215 & 8,4 & 37.050 & $-40,7$ \\
\hline 2013 & 150.981 & 7,7 & 51.987 & 40,3 \\
\hline 2014 & 162.375 & 7,5 & 75.045 & 44,4 \\
\hline 2015 & 176.651 & 8,8 & 63.543 & 15,3 \\
\hline
\end{tabular}

Source of Primary Service Office of Banda Aceh (2016)

From the table above gives an overview of the phenomenon of the condition of the number of registered taxpayers and reported tax returns to KPP Kota Banda Aceh, it appears that the number of registered taxpayers turned out to be much larger and more than the taxpayers who report, of this phenomenon gives an indication that low still awareness of taxpayers to pay taxes. This condition will have an impact on the low government revenue from the tax sector, so it will affect the condition of development.

Factors that can improve taxpayer compliance include tax knowledge and tax awareness. The self-assessment system carries a mission so that people can more easily report and pay their own taxes. But most of the self assessment systems are not very successful. This is seen still low taxpayers who report tax (Darmayanti, 2004). The implementation of self assessment system in the truth of tax payment according to Pancawati (2011) depends on the honesty of the taxpayers themselves in reporting their tax obligations. Taxpayer awareness can be seen from the sincerity and the desire of the taxpayer to fulfill his tax obligation shown in the understanding of the taxpayer on the tax function and the severity of the taxpayer in paying and reporting the tax.

Currently there are still many taxpayers who do not understand the obligations of taxation, it is stated Darmayanti (2004) this incident many happen to new Taxpayers, they often acknowledge that after having NPWP they do not know the consequences thereafter, so when out Tax Assessment Letter ( SKP) in the position, the Taxpayer objected because he felt no previous socialization. Similarly, according to Fuad (2014) people's knowledge about taxes is still minimal, this is one factor of low public awareness to pay taxes, many people do not know, as if to pay taxes must be in the tax office, but the tax office never received money taxes, the perception is causing the people are reluctant to pay taxes, this is because fear that the money spent to pay taxes is used for the benefit of a handful of people, if anyone paid taxes to the tax employee is wrong, just pay the bank.

In addition, the limitation of Taxpayers' knowledge about various matters relating to taxation is risky to reduce the efficiency of time in the process of tax payments and open opportunities for violation of the law. Irregularities can occur because the initiative Taxpayers who want the business quickly completed and because there is an element of error from the tax officials in the field (Kurnianto, 2011).

In the Law of the Republic of Indonesia number 28 of 2009 stated that the tax is a compulsory contribution to the area owed by an individual or a coercive body under the Act, by not getting a reward directly and used for regional purposes for the greatest prosperity of the people . Tax 
INTERNATIONAL JOURNAL OF ACADEMIC RESEARCH IN BUSINESS AND SOCIAL SCIENCES Vol. 8, No. 10, Oct. 2018, E-ISSN: 2222-6990 @ 2018 HRMARS

awareness is another effort in maximizing taxpayer compliance. According Ajzen (2012), Awareness taxation is a moral obligation that each person has in implementing something. Where this can be attributed to the fulfillment of taxpayer compliance in paying PKB. This is similar to the research conducted by Ho (2004) where the tax compliance level will be higher when the taxpayer has a stronger moral obligation. Based on the description, this study aims to examine the influence of tax knowledge, self assessment system and awareness of taxation positively to taxpayer compliance in Banda Aceh City.

\section{Literature Review \\ Taxpayer Compliance}

Compliance with taxation is a condition in which the taxpayer fulfills and implements all tax obligations (Nurmantu, 2010: 148), namely (a) taxpayer compliance in registering; (b) compliance to remit the Notice; (c) compliance in calculating, calculating and paying the tax payable; (d) compliance in reporting and payment of arrears. Identify these indicators in accordance with the tax obligations in the self-assessment system (Devano and Kurnia, 2011: 83-84).

\section{Self Assessment System}

Self assessment system is a tax collection system adopted in Indonesia today (Zain, 2010: 112). Self assessment system is a taxation system that gives trust to Taxpayers to fulfill and implement their own obligations and tax rights (Nurmatu, 2005: 108). Another definition explains that the self assessment system is a tax collection system that authorizes trust and liability to the Taxpayer to calculate, pay, and self-report the amount of tax to be paid (Waluyo, 2007: 17). Under this system, the amount of tax payable specified in the SPT is stipulated by the taxpayer himself.

\section{Taxpayer Awareness}

Artiningsih (2013: 13), taxpayer awareness is the behavior of the taxpayer itself in the form of views or perceptions which involve beliefs, knowledge, and reasoning and the tendency to act in accordance with the stimulus or stimulus provided by the system and the applicable taxation provisions.

Indicators in taxpayers 'awareness include taxpayers' willingness to pay taxes and report tax returns, and the level of order and discipline of taxpayers in paying taxes (Rahayu, 2010: 4). Rahayu (2010: 5) describes some form of tax paying awareness that encourages taxpayers to pay taxes. There are three main forms of awareness regarding tax payments. First, the awareness that taxes are a form of participation in supporting the development of the state. By realizing this, taxpayers are willing to pay taxes because they feel not harmed by tax collection. Tax is realized to be used for the development of the state in order to improve the welfare of the citizens. Second, the realization that the delay in tax payments and the reduction of the tax burden is very detrimental to the state. Taxpayers are willing to pay taxes because they understand that delaying tax payments and reducing the tax burden impacts on the lack of financial resources that can lead to the hampering of state development. Third, the awareness that taxes are established by law and harm the state. can be imposed. Taxpayers will pay because tax payments are aware of having a strong legal basis and is an absolute obligation of every citizen. 
INTERNATIONAL JOURNAL OF ACADEMIC RESEARCH IN BUSINESS AND SOCIAL SCIENCES Vol. 8, No. 10, Oct. 2018, E-ISSN: 2222-6990 @ 2018 HRMARS

\section{The Influence of Tax Knowledge of Taxpayer Compliance}

Tax knowledge is used by taxpayers as tax information in tax actions such as calculating, calculating, paying, and reporting the amount of taxes deposited. Based on the results of research Diatnyani (2010) proves that the knowledge of taxpayers have a positive and significant impact on compliance reporting taxpayer person, meaning the higher the knowledge of taxpayers the higher the compliance of taxpayer reporting of individuals and vice versa.

Rahayu (2010: 141) provides studies on the importance of tax knowledge for taxpayers greatly affect the tax attitudes towards the tax system fair. The existence of a better quality of knowledge will provide the attitude of fulfilling obligations correctly through the existence of a state taxation system that is considered fair. Therefore, the knowledge of taxation owned by the taxpayer will affect the obedience of the taxpayer itself in carrying out its tax obligations. And will also affect the tax revenue received by the state if the people already have high tax knowledge.

Supriyati and Hayati (2012) indicate that tax knowledge affects taxpayers in paying taxes. The more information the taxpayer has on the usefulness of taxes and the better the taxpayer's understanding of taxes, the more obedient the taxpayer to settle his tax obligations.

Ha1: Tax knowledge has a positive effect on taxpayer compliance in Kota Banda Aceh.

\section{Effect of self assessment system on Taxpayer Compliance}

Hutagaol (2016: 3) said that an important assessment to maintain the self-assessment system is a function of supervision against tax compliance. This function is very important because in the self asessment system Taxpayer is given the widest possible freedom in calculating the amount of tax payable that becomes obligation. Ideally, if this function is effective, then the amount of tax payable, reported by the Taxpayer in his SPT should be known to be true.

Palil and Mustapa (2011) emphasize that the main feature of the self-assessment system is the self-finishing of tax returns and tax payments from various levels of background so that simplification of tax returns and administration can potentially help Taxpayers to resolve their tax returns accurately and improve compliance.

Jatmiko (2011) in his research entitled The Effect of Taxpayer Attitude on the Implementation of Fine Sanctions, Fiscal Services and tax awareness of taxpayer compliance in Jakarta City Region "states that taxpayer attitudes toward the service of sanctions fines, fiscal services, and tax awareness Positive and Significant to tax compliance.

Ha2: The self assessment system has a positive effect on taxpayer compliance in Banda Aceh City.

\section{Effect of Taxpayer Awareness on Taxpayer Compliance}

Taxpayer awareness of the taxation function as state financing is needed to improve taxpayer compliance (Agus, 2006: 14). The awareness to become a compliant taxpayer is one of compliance with the law of taxation where it is mentioned that the tax law is indiscriminate and does not escape the exceptions, either anywhere and anybody are all equal under the terms of applicable tax laws to avoid administrative sanctions to be harming the taxpayers themselves. 
Artiningsih (2013) in his research mentions that taxpayer consciousness agencies and tax services have a positive and significant impact on taxpayer compliance level in KPP Pratama Sleman. That is, the higher the awareness of taxpayers then the level of taxpayer compliance is also higher, and vice versa. Agus (2006: 14) states that the consciousness to become a compliant taxpayer is one of compliance with the tax law where it is mentioned that the law of taxation is not indiscriminate and there are no exceptions.

Some researches conducted in Indonesia, among others, Pancawati (2011) and Suryadi (2011) indicate that the consciousness of taxpayers affect taxpayer compliance to pay taxes. The higher the taxpayer's awareness to pay taxes. The more obedient the taxpayer to pay taxes.

Ha3: Tax awareness has a positive effect on taxpayer compliance in Banda Aceh City

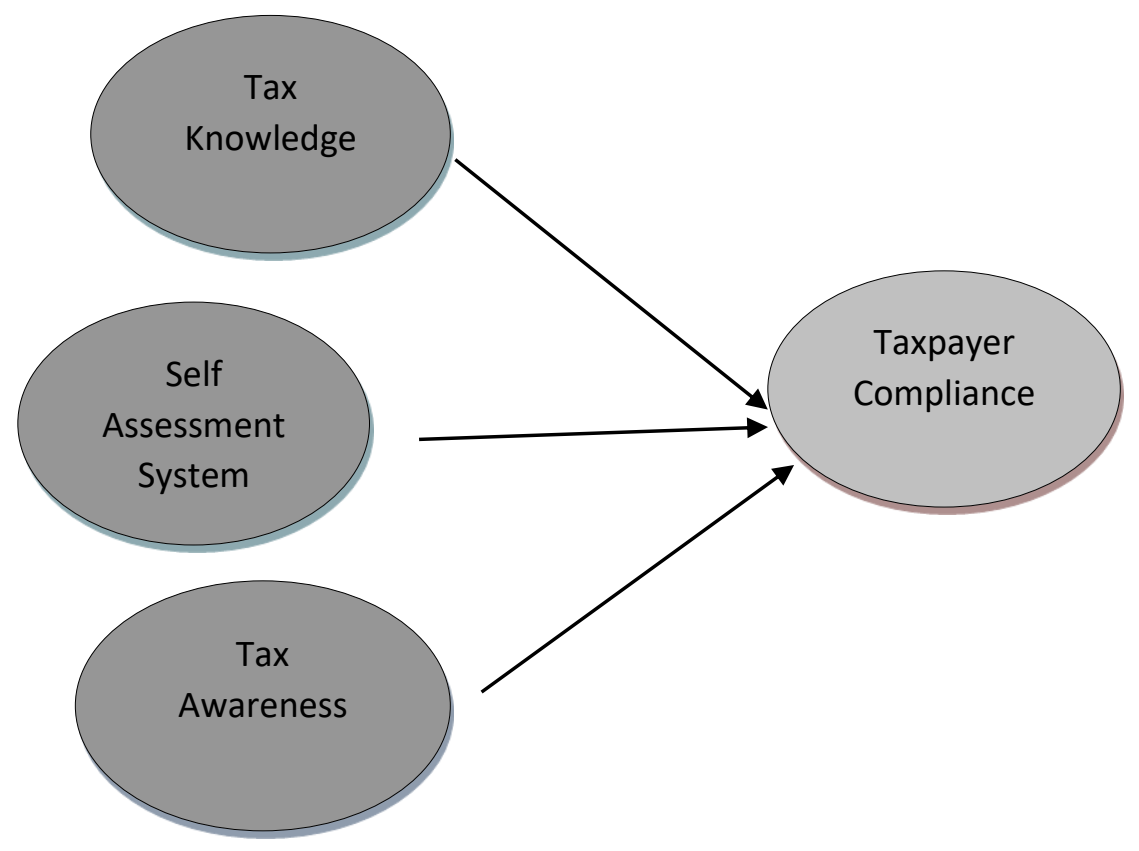

\section{Research Methods}

\section{Hypothesis Testing Method}

To test hypothesis 1 (Ha1), hypothesis 2 ( $\mathrm{Ha} 2)$, and hypothesis 3 (Ha3) used multiple linear regression analysis as follows:

$$
T C_{i}=\alpha_{0}+\beta_{1} T K_{i}+\beta_{2} S A S_{i}+\beta_{3} T A_{i}+\varepsilon_{i}
$$

Where :

TCi : is tax compliance of taxpayer $\mathrm{i}$;

TKi : is tax knowledge of taxpayer $\mathrm{i}$;

SASi : is Self Assessment System of taxpayer i;

TAi : is tax awareness of taxpayer

I $\quad$ : $\alpha$ is constanta; 
INTERNATIONAL JOURNAL OF ACADEMIC RESEARCH IN BUSINESS AND SOCIAL SCIENCES

Vol. 8, No. 10, Oct. 2018, E-ISSN: 2222-6990 ㄷ 2018 HRMARS

$\beta 1, \beta 2, \beta 3$ : is coefficient of independent variables;

हi : is error terms.

To test the significance of tax knowledge, self-assessment system, and tax awareness to tax compliance, it is used $t$ test.

\section{Research Result}

\section{Hypothesis Testing Results}

To know the influence of taxation knowledge, self assessment system and tax awareness to taxpayer compliance in Banda Aceh City will be tested by using multiple linear regression. The results of his research can be seen in Table 8.

Table 2

Regression Calculation Result

\begin{tabular}{|c|c|c|c|}
\hline \multicolumn{4}{|c|}{ Multiple Linear Regression Equation } \\
\hline \multicolumn{4}{|c|}{$Y=0,585+0,533 X_{1}+1,545 X_{2}+0,106 X_{3}+e$} \\
\hline Variable & Koefisien Regresi & $t-$ count & Signifikansi \\
\hline (Constant) & 0,585 & 2,946 & 0,004 \\
\hline Knowledge of taxation & 0,533 & 2,428 & 0,017 \\
\hline Self assessment system & 1,545 & 3,712 & 0,000 \\
\hline Tax awareness & 0,106 & 2,561 & 0,026 \\
\hline$R=0,966$ & & & \\
\hline$R^{2}=0,934$ & & & \\
\hline Adj $R^{2}=0,931$ & & & \\
\hline $\mathrm{F}=449,439 \quad$ Sig $=0,00$ & & & \\
\hline Signifikansi pada $\alpha 5 \%$ & & & \\
\hline
\end{tabular}

Sumber: Hasil Pengolahan Data, 2017 (Diolah)

From the research results obtained the final equation estimator are: $Y=0.5850 .533 \times 1$

$1.545 \times 20.106 \times 3$ e. The equation implies that:

- Constanta of 0,585, meaning that if Variable knowledge of taxation, self assessment system and awareness of taxation is considered constant then taxpayer compliance equal to 0,585 percent.

- If Variable knowledge of taxation changes 1 percent then it will affect the taxpayer compliance increase of 0.533 percent assuming Variable self-assessment system and tax awareness is considered fixed.

- If the self-assessment system variables increased by 1 percent then the effect on taxpayer compliance increase of 1.545 percent assuming Variable knowledge taxation and tax awareness is considered fixed.

- If Variable awareness of taxation increased by 1 percent then the effect on taxpayer compliance increase of 0.106 percent assuming Variable knowledge taxation and self assessment system is considered fixed.

- The correlation coefficient (R) of 0.966 which illustrates that knowledge of taxation, self assessment system and tax awareness have closeness relationship to taxpayer compliance of 96.6 percent. 
- Adj R2 coefficient worth 0.931 indicates that the variation of taxation knowledge, self assessment system and tax awareness affect the taxpayer compliance variation of 93.1 percent and the remaining 6.9 percent is influenced by other variables outside this research model.

Evidence Variable knowledge of taxation and tax awareness of taxpayer compliance in the City of Banda Aceh then be tested separately partially. The results obtained are as follows:

- For Variable knowledge of taxation obtained t-count value of 2.428 is greater than the value of ttable $=1.9850$ means Variable knowledge of taxation partially significant effect on taxpayer compliance.

- For self assessment system variables obtained t-count value of 3.712 is greater than the value of $\mathrm{t}$-table $=1.9850$ means that the variable self assessment system partially affect taxpayer compliance.

- For Variable awareness of taxation obtained t-count value of 2.561 greater than the value of $t$ table $=1.9850$ means that the variable awareness of taxation partially affect taxpayer compliance.

\section{Discussion}

Tax Knowledge Analysis, Self Assessment System and Tax Awareness on Taxpayer Compliance in Banda Aceh City

From the research results obtained F-count value of 449 greater than the value of F-table $=$ 2.699. This means that knowledge of taxation, self assessment system and tax awareness together have a significant effect on taxpayer compliance in Banda Aceh City. Thus it can be concluded that the formulated hypothesis can not be rejected. This means that simultaneously Variable knowledge of taxation, self assessment system and tax awareness simultaneously affect taxpayer compliance.

Based on the above phenomenon it can be assumed that this research model is used to mem [knowledge taxpayer prediction in Banda Aceh has value R2 equal to 0,934 meaningful that knowledge of taxation, self assessment system and tax awareness influence to taxpayer compliance equal to 93,4 percent and the remaining 6.6 percent is influenced by other variables outside of this research model. This is in line with research with previous research, Diatnyani (2010), Rahayu (2010: 141), Hutagaol (2017), Yulianto (2009) and Artiningsih (2013).

\section{The Influence of Tax Knowledge of Taxpayer Compliance in Banda Aceh City}

The results of data for Variable knowledge of taxation partially have a significant and positive effect on taxpayer compliance. The positive direction indicates that the higher the level of taxation knowledge will be the higher taxpayer compliance and the lower the tax knowledge will be lower taxpayer compliance.

The findings are consistent with research conducted by Diatnyani (2010) proves that the knowledge of taxpayers has a positive and significant impact on compliance of taxpayer reporting person. This means that the higher the knowledge of taxpayers will be the higher compliance reporting taxpayers of individuals and vice versa.

This research is also in line with the research conducted by Rahayu (2010: 141), which states that the aspect of tax knowledge for taxpayers greatly affect the taxpayer's attitude to the tax system fair. The existence of a better quality of knowledge will provide the attitude of fulfilling obligations 
correctly through the existence of a state taxation system that is considered fair. Therefore, the knowledge of taxation owned by the taxpayer will affect the obedience of the taxpayer itself in carrying out its tax obligations. And will also affect the tax revenue received by the state if the people already have high tax knowledge.

\section{Effect of Self Assessment System on Taxpayer Compliance in Banda Aceh City}

The results of this study indicate that the self assessment system is partially significant and positive impact on taxpayer compliance. The positive direction indicates that the higher the self assessment system the higher the taxpayer compliance and the lower the self assessment system, the lower the taxpayer compliance.

These findings are in accordance with research conducted by Hutagaol (2017: 3) which states that an important assessment to maintain the self-assessment system is a function of supervision against tax compliance. This function is very important because in the self asessment system Taxpayer is given the widest possible freedom in calculating the amount of tax payable that becomes obligation. Ideally, if this function is effective, then the amount of tax payable, reported by the Taxpayer in his SPT should be known to be true. The research conducted by Yulianto (2009) states that the implementation of the self assessment system policy has an effect on the compliance of individual Taxpayer. Improving the effectiveness of the implementation of the self assessment policy will affect the improvement of individual taxpayer compliance, Efforts to optimize the organization, interpretation and application will significantly improve the compliance of individual Taxpayers. Palil and Mustapa (2011) also stressed that the main feature of the self assessment system is the selffinishing of tax returns and tax payments from various levels of background so that simplification of tax returns and administration can potentially help Taxpayers to resolve their tax returns accurately and improve compliance.

\section{The Effect of Tax Awareness on Taxpayer Compliance in Banda Aceh City}

The results of the research for tax awareness variables obtained partially have a significant and positive impact on taxpayer compliance. The positive direction indicates that the higher the awareness of taxation, the higher the taxpayer compliance and the lower the tax awareness, the lower the taxpayer compliance.

These findings are in accordance with research conducted by Artiningsih (2013) which in his research stated that the taxpayer's awareness of the agency and tax services have a positive and significant impact on taxpayer compliance level. That is, the higher the awareness of taxpayers then the level of taxpayer compliance is also higher, and vice versa. Agus (2006: 14) states that the consciousness to become a compliant taxpayer is one of compliance with the tax law where it is mentioned that the law of taxation is not indiscriminate and there are no exceptions.

\section{Conclusion}

Based on the results of research that has been done then it can be taken conclusion that is:

1. Taxation knowledge, self assessment system and tax awareness simultaneously have a significant effect on taxpayer compliance in Banda Aceh City. This higher the knowledge of taxation, self assessment system and tax awareness then the higher taxpayer compliance. 
INTERNATIONAL JOURNAL OF ACADEMIC RESEARCH IN BUSINESS AND SOCIAL SCIENCES

Vol. 8, No. 10, Oct. 2018, E-ISSN: 2222-6990 @ 2018 HRMARS

2. Taxation knowledge, self assessment system and tax awareness partially significant effect on taxpayer compliance in Banda Aceh City. This higher the knowledge of taxation, self assessment system and tax awareness then the higher taxpayer compliance

3. Variation of taxation knowledge, self assessment system and tax awareness affect the taxpayer compliance variation of 93.1 percent and the rest of 6.9 percent is influenced by other variables outside of this research model.

\section{References}

Agus, N. (2006). Pengaruh Sikap Wajib Pajak pada Pelaksanaan Sanksi Denda, Pelayanan Fiskus dan Kesadaran Perpajakan terhadap Kepatuhan Wajib Pajak Studi Empiris terhadap Wajib Pajak Orang Pribadi di Kota Semarang. Tesis Magister Akuntansi. Program Pascasarjana Universitas Diponegoro

Ajzen, C. (2012). Kesadaran Perpajakan. Jakarta: Erlangga.

Artiningsih. (2013). Pengaruh Kesadaran Wajib Pajak Badan dan Pelayanan Perpajakan terhadap Kepatuhan Wajib Pajak di KPP Pratama Sleman. Jurnal Akuntansi Keuangan. Vol 3 No 2: 3847.

Chandra, B. (2014). Buka Rahasia Bank untuk Pajak. Diakses dari: http://www.investor.co.id/home/buka-rahasia-bank-untuk-pajak/79026.

Chau, D. (2009). Understanding The Compliance Behaviour of Malaysian Individual Taxpayers Using a Mixed Method Approach. Journal of the Australasian Tax Teachers Association, Vol.4 No.1: 181-202.

Darmayanti. (2004). Perpajakan: Konsep, Teori, dan Isu. Jakarta: Prenada Media Group.

Devanom S. dan Kurnia, S.R. (2011). Perpajakan: Konsep, Teori dan Isu. Jakarta: Kencana.

Diatnyani. (2010). Pengaruh Kesadaran Wajib Paak terhadap Kepatuhan Pelaporan Wajib Pajak Orang Pribadi. E-Jurnal Akuntansi Universitas Udayana.

Fua, R. (2014). Baru 30 Persen Potensi Pajak yang Tergali. Diakses Melalui: http://pemilu.tempo.co/read/news/2014/03/24/087564947/Baru-30-Persen PotensiPajak-yang-Tergalio.

Haroen, H.A.R. (2013). Pengetahuan Mengenai Pajak Belum Optimal. Diakses dari: http: // pikiran rakyat online.com /read/2013/10/22/252356 /2093994/1/pengetahuan mengenai pajakbelum-optimal.

Ho, D. (2004). A Study of Hongkong Tax Complience Ethies. International Business Research. Vol 2 No 4: 113-121.

Hutagaol, J. (2016). Perpajakan: Isu-isu Kontemporer. Yogyakarta: Graha Ilmu.

Jatmiko, D. A. N. (2011). Pengaruh Sikap Wajib Pajak pada Pelaksanaan Sanksi Denda Pelayanan Fiskus, dan Kesadaran Perpajakan Terhadap Kepatuhan WajibPajak Studi Empiris Terhadap Wajib Pajak Orang Pribadi di Kota Semarang. Universitas Diponegoro.

Kurnianto, S. (2011). Direktur Eksekutif Ikatan Akuntan Indonesia Jawa Timur: wp banyak tak tahu teknis dan aturan perpajakan. Surabaya: http://www.bisnisjatim.com/index.php/2011/01/21/wp-banyak-tak-tahu-teknis-dan-aturan-perpajakan/, 21 januari. 
INTERNATIONAL JOURNAL OF ACADEMIC RESEARCH IN BUSINESS AND SOCIAL SCIENCES

Vol. 8, No. 10, Oct. 2018, E-ISSN: 2222-6990 ㄷ 2018 HRMARS

Lestari. P. (2010). Analisis Tingkat Pemahaman Wajib Pajak Badan terhadap Pelaksanaan Self Assessment Sytem dalam Pelaporan SPT Tahunan Pajak Penghasilan PPh. Badan di KPP Pratama Denpasar Timur. Jurnal Saintikom. Vol. 5. No 3: 81-92.

Palil, M.R. dan Ahmad, F.M. (2011). Determinan of Tax Compliance in Asia: a case of Malaysia. Jurnal Akuntansi dan Keuangan. Vol.7 No.1: 11-21.

Pancawati, H. dan Nil. Y. (2011). Faktor-Faktor yang Mempengaruhi Kemampuan Membayar Pajak. Dinamika Keuangan dan Perbankan. Vol 3. No1: 126-142.

Nurmantu, S. (2012). Pengantar Perpajakan; edisi 2, Jakarta: Granit.

Rahayu, S.K. (2010). Perpajakan Indonesia, Konsep dan Aspek Formal. Bandung: Graha Ilmu.

Ruyadi. (2012). P erpajakan Indonesia. Edisi Kedua, Jakarta: Salemba Empat.

Tarjo dan Indra, K. (2006). Analisis Perilaku Wajib Pajak Orang Pribadi terhadap Pelaksanaan Self Assessment System: Suatu Studi di Bangkalan. JAAI, Juni 2006. 101: 101-120.

Waluyo. (2012). Akuntansi Pajak. Edisi Empat. Jakarta Selatan: Salemba Empat.

Yoepidha L.S (2012). Masih Minimnya Wajib Pajak Untuk Melapor Pajak Penghasilan. Diakses dari: http://finance. detik.com/read/2012 /05/14/112842/1983897/6/minim-lapor pajak.

Zain, M. (2010). Manajemen Perpajakan. Jakarta: Salemba Empat. 